\title{
In vivo assessment of the diaphragm in young male healthy adults: occupation-based activity-related differences
}

\section{Ocena in vivo stanu przepony u zdrowych, młodych mężczyzn - różnice uwarunkowane poziomem zawodowej aktywności fizycznej}

\author{
Ogugua Augustine Egwuํ, Elizabeth Bello², Clinton Ogbonnaya Njoku² \\ ${ }^{1}$ Department of Anatomy, Federal University, Ndufu-Alike Ikwo, Ebonyi State, Nigeria \\ ${ }^{2}$ Department of Anatomy, Ebonyi State University, Abakaliki, Nigeria
}

Key words: diaphragm, thickness of diaphragm, occupation-related strength training, Africa.

Słowa kluczowe: przepona, grubość przepony, wysiłek siłowy związany z wykonywanym zawodem, Afryka.

\begin{abstract}
Introduction: Very little attention has been paid to the thickness of the diaphragm (DT) as an important aspect of architecture of the respiratory muscle and the possible effect of occupation-related unregulated physical activity on it.

Aim of the research: This study aimed at assessing the effect of occupation-based physical activity on the thickness of the thoracic diaphragm.

Material and methods: Eighty (80) males between the ages of 18 and 30 years were recruited for the study and divided into two (2) groups: a control group of forty (40) relatively inactive subjects and a quasi-experimental group of forty (40) peasant labourers. The peasant labourers were recruited from a settlement of local craftsmen and motor-mechanic artisans. B-mode ultrasound was used to measure the thickness of the diaphragm (DT).

Results: The mean DT of the quasi-experimental group was higher than that of the control group $(p>0.05$ - not significant), even though the control group presented significantly greater weight and body mass index $(p<0.05)$ than the age-matched Labourers.

Conclusions: These findings indicate that occupation-based unregulated physical activity increases DT and may initiate the setting in of diaphragmatic hypertrophy induced by occupation-associated strength and anaerobic training. The findings will also serve as a guidepost in the biomechanical aspects of the muscle during respiration in our sub-Saharan African population.
\end{abstract}

\section{Streszczenie}

Wprowadzenie: Do tej pory bardzo niewiele uwagi poświęcano grubości przepony (GP), która jest istotnym elementem architektury mięśni oddechowych, jak również ewentualnemu wpływowi nieregulowanej aktywności fizycznej związanej z wykonywanym zawodem na stan przepony.

Cel pracy: Ocena wpływu nieregulowanej aktywności fizycznej związanej z wykonywanym zawodem na grubość przepony.

Materiał i metody: Do badania włączono 80 mężczyzn w wieku 18-30 lat. Uczestników podzielono na dwie grupy: grupe kontrolną liczącą 40 mężczyzn o relatywnie niskim poziomie aktywności fizycznej oraz quasi-eksperymentalną grupę dopasowanych wiekiem 40 pracowników fizycznych. Rekrutację pracowników fizycznych na potrzeby badania przeprowadzono wśród miejscowych rzemieślników i mechaników samochodowych. Pomiary GP przeprowadzono metodą ultrasonograficzną $\mathrm{w}$ trybie B-mode.

Wyniki: Wykazano, że średnia GP w grupie quasi-eksperymentalnej jest większa niż w grupie kontrolnej $(p>0,05$ - brak istotności statystycznej), mimo że członkowie grupy kontrolnej odznaczali się znacznie większą masą ciała i wskaźnikiem masy ciała $(p<0,05)$ niż dopasowani wiekiem pracownicy fizyczni.

Wnioski: Nieregulowana zawodowa aktywność fizyczna zwiększa GP i może się przyczyniać do przerostu przepony na skutek wysiłku siłowego i anaerobowego związanego z wykonywanym zawodem. Uzyskane wyniki wzbogacają również wiedzę na temat biomechaniki pracy mięśni podczas oddychania w populacji osób z Afryki Subsaharyjskiej. 


\section{Introduction}

Thoracic diaphragm is defined as a large sheet of muscle that partitions the intra-abdominal cavity from the thoracic cavity [1]. As a skeletal muscle, its architecture plays an important role in its function $[2,3]$. As a result, knowledge of its architecture will be of great practical importance in understanding the relationship between its structure, force, and extension ability [4]. The muscle architecture is mainly characterised by fascicle length, pennation angle, and the thickness of the muscle [5-7]. The length of the fascicle plays a role in force generation during highspeed contractions, while the fascicle pennation angle and muscle thickness are the relevant factors for overall force generation [3]. Since muscle thickness is relevant in overall force generation, the diaphragm being a muscle sine qua non in the force generating phases of mechanical respiration should be investigated.

Also, considering the functional role of the diaphragm in venous return by increasing intra-abdominal pressure [8-13], along with its role in assisting the maintenance of vertebral and core stability, emesis, coughing, and deglutition [14-22], it is even more important to carry investigate the structural disposition of the diaphragm.

Previous studies have tried to assess the diaphragm as a skeletal muscle by using B-mode ultrasound, and they have established the reliability of the method in their investigations [23-27]. These studies and some others also investigated the structural inclination of the diaphragm in relation to age, stature, degree of physical activity, and disease. Ueki et al. [24] assessed the thickness of the diaphragm using different degrees of contraction in a European population; Misuri et al. [28] assessed the thickness of other respiratory muscles - anterolateral and strap abdominal muscles - during degrees of contraction. They both observed changes in the muscles associated with different degrees of inspiration and expiration.

Arora and Rochester [29] assessed the effect of alteration of body weight and muscularity on the mass, thickness, and length of diaphragm in necropsy and concluded that alterations in body weight and muscularity profoundly affect diaphragm muscle mass, causing a nearly threefold variation between muscular normal subjects and underweight patients.

McCool et al. [25] while investigating anthropometric relationships of the diaphragm established that the structural dimensions of the diaphragm and thorax show substantial variability, some of which is systematic with stature; the variations of structure predict substantial variation of inspiratory strength, which is not systematic with stature, and that the muscular cross-section of the diaphragm is increased by general or specific training. More recently, some studies have shown that the diaphragm increases its thickness when a resistance is applied against it during weight lifting training [21]. Also, there is about an $8-12 \%$ increase in the diaphragm thickness during contraction after muscular inspiratory post-training for 4 weeks [30].

These relationships, diaphragmatic anthropometric and physical activity, have not been investigated in a sub-Saharan African environment, and knowing the huge importance of the diaphragm in the phases of mechanical respiration, which has also been investigated in disease conditions $[29,31]$, it is absolutely necessary to investigate and compare the structural inclination of the respiratory muscle between a population whose occupation is characterised by different degrees of weight training and crude physical activity and those who are relatively inactive or sedentary.

The subjects who carry out these unrestrained degrees of physical activity are involved in lifting building materials, car engines, and labourer's tools as a result of the lack of mechanisation that has characterised our sub-Saharan African environment. Therefore, hypothetically, we believe that the tone of these degrees of physical activity may affect the structural disposition of this important respiratory muscle, going by previous investigations [29].

Since the investigation will give an accurate insight into diaphragmatic architecture, the findings will possibly be a guidepost to the biomechanical aspects of the diaphragm in our sub-Saharan African population and in the assessment of its functions in disease and in healthy conditions.

\section{Aim of the research}

The aim of the study is to assess the thickness of the thoracic diaphragm in an adult Nigerian population in relation to the occupation based degrees of physical activity of the subjects.

\section{Material and methods}

\section{Study design}

This is a quasi-experimental study designed to use brightest mode ultrasound in measuring the normal thickness of the diaphragm.

\section{Participants}

The sampling method is that of a convenient purposive nature. Eighty healthy male subjects were recruited for this study. Only males were recruited due to a certain level of masculine uniformity characterised by post-pubertal development. Forty subjects were used as controls and were selected from a student population in the College of Medicine, Presco Campus, Ebonyi State University, Abakaliki, Southeast Nigeria. The other quasi-experimental group of 40 subjects is an age-matched group selected from a settlement of peasant labourers/artisans in a motor mechanic village and building materials market in Abakaliki metropo- 
lis, Southeast Nigeria. These individuals are involved in digging/tilling, lifting cement bags and other building materials, local mining, and concrete blending for a minimum period of 1 year, and these activities formed their sole occupation and source of income. All subjects were physically active and had not previously taken part in planned regular weight training (weight lifting). None had any subjective clinical evidence of musculoskeletal injury or any orthopaedic abnormality. They were all asked to avoid any physical activity or exercise (e.g. running, cycling, footballing, etc.) for at least 2 weeks before the study as this has been found to cause an increase in muscle thickness [21, 30].

\section{Study area}

Abakaliki is the capital city of Ebonyi state, which is a mainland southeastern state of Nigeria, inhabited and populated primarily by Igbos of Southeastern Nigeria. It lies approximately within longitude $7^{\circ} 30^{\prime}$ and $7^{\circ} 30^{\prime} \mathrm{E}$ and latitude $5^{\circ} 40^{\prime}$ and $60^{\circ} 45^{\prime} \mathrm{N}$. It has a landmass of about 5,935 square kilometres. The population of Ebonyi state according to the census of March, 2006 is $2,176,947$ peoples.

\section{Study centre}

The study centre was at Life Scan Ultrasound Centre, Felix Memorial hospital, 7 Hill-top road, Abakaliki, Ebonyi state, Southeast Nigeria. This study centre receives patients from within the Abakaliki metropolis and beyond. Most of their patients are obstetric patients and individuals with soft tissue pathologies, including all forms of abdominal

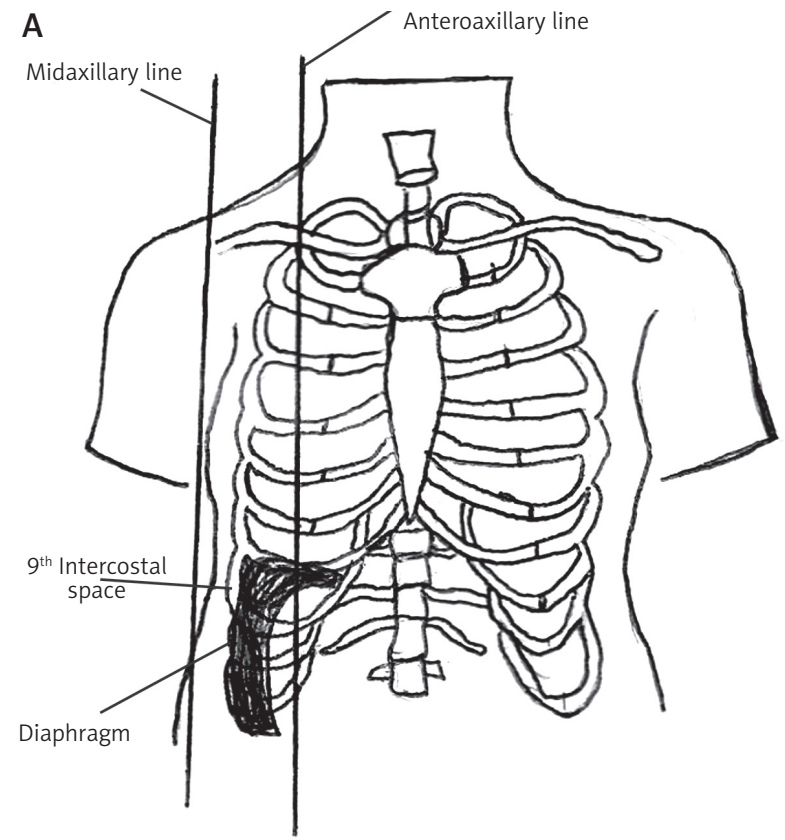

Figure 1. A - Landmark showing measurement. B - Subject pathologies. They also receive patients from all private hospitals in the Abakaliki metropolis, Ogoja Metropolis, Afikpo metropolis, and beyond, as well as those not accommodated in the state Federal Teaching Hospital, Abakaliki, Ebonyi state, Southeast Nigeria [32]. The centre is licensed as the imaging unit of the Department of Anatomy, Faculty of Basic Medical Sciences, Ebonyi State University, Abakaliki, Southeast Nigeria.

\section{Instrumentation}

A brightness mode (B-mode) ultrasound system (Siemens sonoline SL-1, Version 1991) was used to objectively measure the diaphragm thickness with a $7.5 \mathrm{MHz}$ linear transducer.

\section{Scanning protocol}

The subjects lay in a supine position with relaxed breathing while the measurements were taken. The ultrasound transducer was held perpendicular to the chest wall, and transverse views of the diaphragm were obtained with the measurement taken at the point where the diaphragm was seen to be thickest on the right dome. This point is the zone of apposition, which is in the line of the $9^{\text {th }}$ intercostal space between the anteroaxillary and midaxillary line, $0.5-2 \mathrm{~cm}$ below the costophrenic sinus, as described by Ueki et al. [24] (Figure $1 \mathrm{~A}$ and B). The inferior border of the costophrenic angle was easily identified by the level of the lung artefact caused by the ultrasound reflected by the air in the lung. The diaphragm was outlined by two clear bright parallel lines of the pleural and peritoneal membranes (Figures 2 and 3) [33].

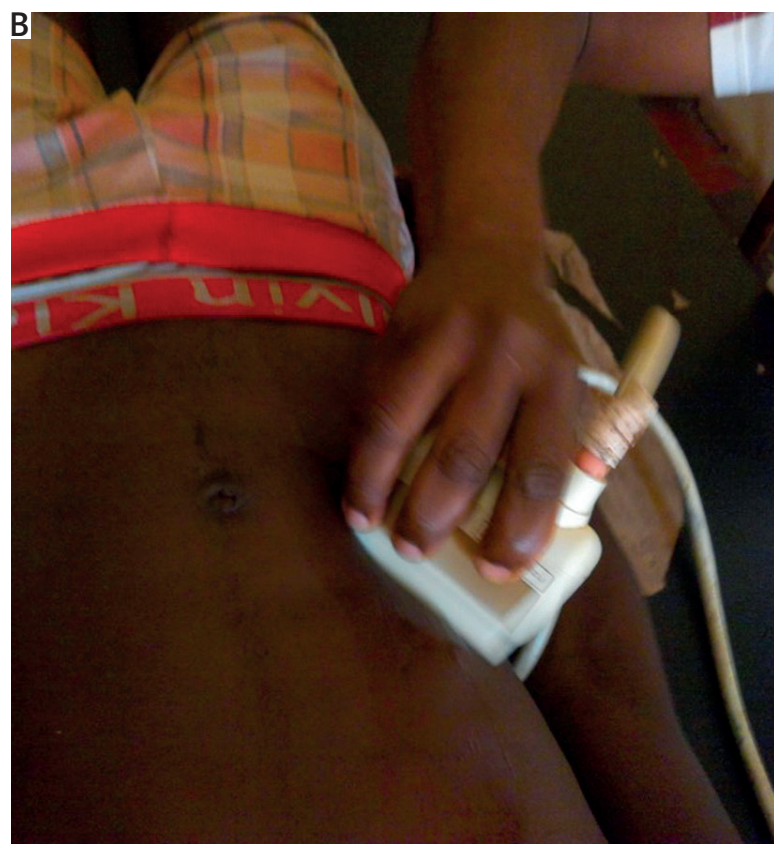



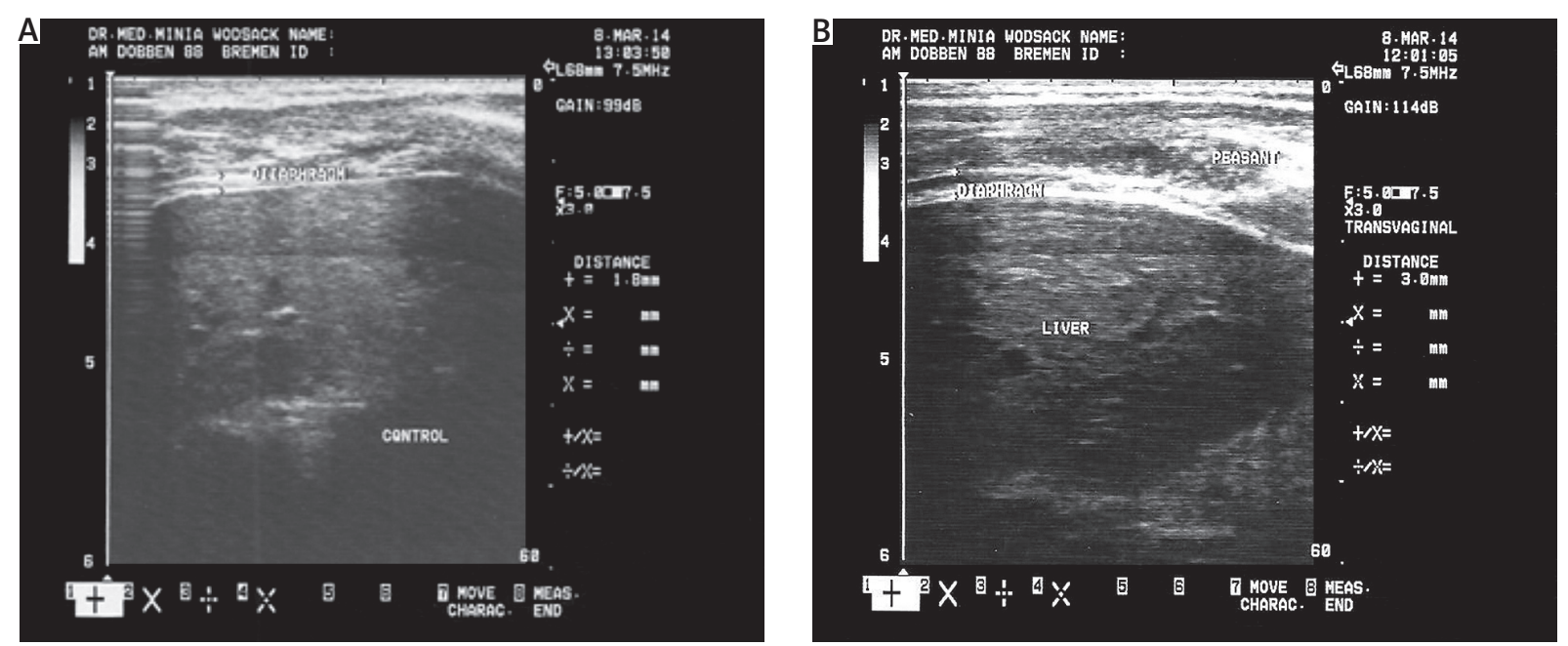

Figure 2. A - Sonogram of controls. B - Sonogram of peasant labourers

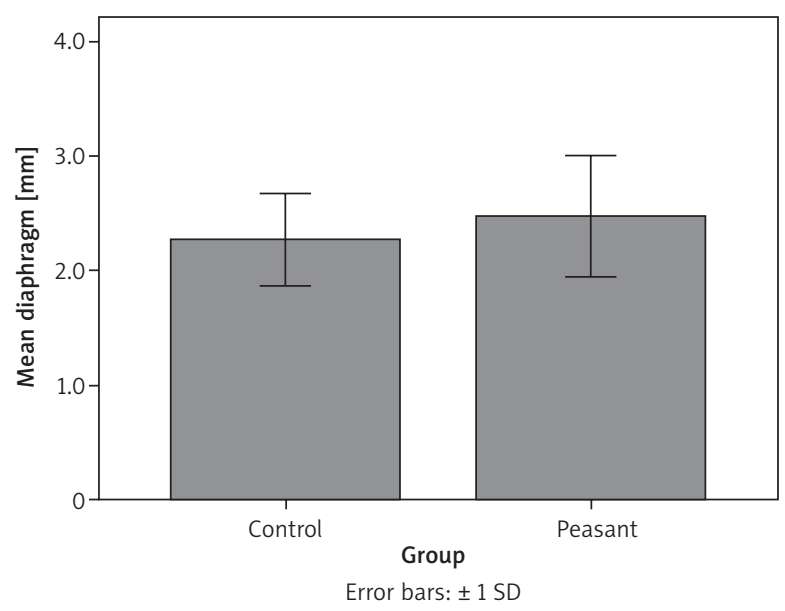

Figure 3. Graphical representation of the normal thickness of the diaphragm in the two groups

\section{Anthropometric measurements}

Anthropometric parameters such as height, and weight were all measured for each of the subjects for data analysis. Age of the subjects was also assessed through verbal confirmation by the subjects.

\section{Weight}

The body weight was measured using a bathroom scale in kilograms $(\mathrm{kg})$. This scale was at the zero scale reading before measuring each subject. The subjects wore very light clothing to ensure the greatest possible accuracy.

\section{Height}

Height was measured using a Stadiometer in meters (m). The subjects stood erect and their heads were placed parallel to the Frankfort plane to ensure accuracy.
Age

The age of each subject was also taken; their age ranged from 18 years to 35 years.

\section{Body mass index and body surface area}

Body mass index (BMI) was derived using the formula weight/(height ${ }^{2}$ while body surface area (BSA) was derived using the equation derived by Du Bois and Du Bois [34], i.e. BSA $=$ (weight $0.425 \times$ height $0.725) \times 0.007184$.

\section{Statistical analysis}

Data was analysed using the statistical package for social sciences (SPSS) version 20. Data were presented as means \pm standard deviation. Student's $t$-test was used to compare means while bivariate Pearson's correlation was used to establish relations between variables. Values of $p<0.05$ was regarded as being significant.

\section{Ethical consideration}

In line with the Helsinki declaration of 1989, ethical approval was obtained from the Research/Ethics Committee of the Faculty of Basic Medical Sciences, Ebonyi State University, Abakaliki, Southeast Nigeria after the subjects gave written consent to partake in the study.

\section{Results}

Table 1 shows that the peasant labourers had a slightly thicker diaphragm thickness (DT) than the relatively sedentary controls, even though the latter group had a mean greater age and even weighed more.

Table 2 shows that the weight and BMI of the control group were significantly greater than those of the 
peasants, while there was no significant difference in DT between the groups.

Table 3 shows correlations between DT and age, height, weight, and BSA only in the peasant labourer group. There was no correlation seen in the control or relatively sedentary group.

\section{Discussion}

Accurate knowledge of the normal thickness of the diaphragm as a respiratory muscle is important in the quantitative and qualitative assessment of diaphragmatic function and in the precise diagnosis of associated muscular dystrophy, paralysis, and inactivity.

The results from this study have established values for DT in a sub-Saharan African setting. It has revealed that the mean DT for the peasant labourers is 2.48 $\pm 0.53 \mathrm{~mm}$ (range: $1.7-3.5 \mathrm{~mm}$ ) and is slightly higher than that of the relatively sedentary control group with a value of $2.28 \pm 0.40 \mathrm{~mm}$ (range: $1.70-3.0 \mathrm{~mm}$ ) (Table 1). Even though the difference is not significant, it is another possible indication of activity-related differences associated with the occupation of these male subjects. This finding corroborates that of Enright et al. [21]. However, in their report, the degree of activity was planned and monitored over a period of 2 weeks. The observed difference was also not significant in the relaxed state. In the case of our study, the subjects were involved in indiscriminate and crude degrees of hard labour ranging from lifting heavy objects to the transfer of these objects to unimaginable distances - events that have been part of their occupation over a long period of time (a minimum of 1 year). And these events may have a more encompassing effect on the musculoskeletal system, of which the diaphragm is also a part. Conversely, this may be a positive indication of a more functional diaphragm and possibly a better respiratory function, as indicated by previous studies [21, 25].

Other results from this study show that the mean weight and BMI of the inactive control group (69.5 $\pm 710.47 \mathrm{~kg} ; 22.98 \pm 2.06 \mathrm{~kg} / \mathrm{m}^{2}$ ) was significantly greater than that of the labourers $(63.05 \pm 7.76 \mathrm{~kg}$;
Table 1. Descriptive statistics for all parameters measured

\begin{tabular}{|lccc|}
\hline Parameters & Mean & $\begin{array}{c}\text { Standard } \\
\text { deviation }\end{array}$ & $\boldsymbol{N}$ \\
DT [mm]: & 2.48 & 0.53 & 40 \\
Labourers & 2.28 & 0.40 & 40 \\
Control & & & \\
Age [years]: & 23.25 & 4.72 & 40 \\
Labourers & 25.15 & 2.52 & 40 \\
Control & & & \\
Height [m]: & 1.73 & 0.05 & 40 \\
Labourers & 1.74 & 0.07 & 40 \\
Control & & & \\
Weight [kg]: & 63.05 & 7.76 & 40 \\
Labourers & 69.50 & 10.47 & 40 \\
Control & & & \\
BMI: & 21.13 & 2.06 & 40 \\
Labourers & 22.98 & 3.09 & 40 \\
Control & & & \\
BSA: & 1.75 & 0.12 & 40 \\
Labourers & 1.83 & 0.14 & 40 \\
Control & & & \\
\hline
\end{tabular}

$21.13 \pm 2.06 \mathrm{~kg} / \mathrm{m}^{2}$ ). Could this be linked to nutrition associated with the differential class of the subjects or due to a certain degree of inactivity in the control group. Previous reports by $\mathrm{McCool}$ et al. [25], Dureuil and Matuszak [35], and Kelsen et al. [36] suggest that greater weight should reflect greater values of DT. But in this case, the subjects with the greater weight have thinner diaphragms. Therefore, it is possible that the higher DT observed in the peasant labourers may represent the setting in of activity-related diaphragmatic hypertrophic stimulation since the subjects are involved in occupation-related strength and anaerobic training.

Table 2. Student's $t$-test comparison of means of parameters between the two groups

\begin{tabular}{|lcccc|}
\hline Parameter & Labourers, mean \pm SD & Control, mean \pm SD & $t$-Test & Value of $p$ \\
Age [years] & $23.25 \pm 4.72$ & $25.15 \pm 2.52$ & 1.588 & 0.121 \\
Height $[\mathrm{m}]$ & $1.73 \pm 0.05$ & $1.74 \pm 0.07$ & 0.682 & 0.499 \\
Weight $[\mathrm{kg}]$ & $63.05 \pm 7.76$ & $69.50 \pm 10.47$ & $2.214^{*}$ & 0.033 \\
BMI $\left[\mathrm{kg} / \mathrm{m}^{2}\right]$ & $21.13 \pm 2.06$ & $22.98 \pm 3.08$ & $2.233^{*}$ & 0.031 \\
BSA & $1.75 \pm 0.12$ & $1.83 \pm 0.14$ & 1.989 & 0.054 \\
Diaphragm thickness DT $[\mathrm{mm}]$ & $2.48 \pm 0.53$ & $2.28 \pm 0.40$ & -1.388 & 0.173 \\
\hline
\end{tabular}

Significant difference at ${ }^{*} p<0.05$. 
Table 3. Bivariate Pearson's correlation between DT and other parameters

\begin{tabular}{|c|c|c|}
\hline \multirow[t]{2}{*}{ Parameter } & \multicolumn{2}{|c|}{ Diaphragm [mm] } \\
\hline & $\begin{array}{c}\text { Correlation } \\
\text { coefficient }(r)\end{array}$ & Value of $p$ \\
\hline \multicolumn{3}{|l|}{ Age [years]: } \\
\hline Labourers & $0.504^{*}$ & 0.024 \\
\hline Control & -0.279 & 0.233 \\
\hline \multicolumn{3}{|l|}{ Height [m]: } \\
\hline Labourers & $0.484^{*}$ & 0.031 \\
\hline Control & 0.221 & 0.348 \\
\hline \multicolumn{3}{|l|}{ Weight [kg]: } \\
\hline Labourers & $0.538^{\star}$ & 0.014 \\
\hline Control & -0.287 & 0.220 \\
\hline \multicolumn{3}{|l|}{ BMI $\left[\mathrm{kg} / \mathrm{m}^{2}\right]$ : } \\
\hline Labourers & 0.388 & 0.091 \\
\hline Control & -0.424 & 0.062 \\
\hline \multicolumn{3}{|l|}{$\mathrm{BSA}\left[\mathrm{m}^{2}\right]$ : } \\
\hline Labourers & $0.572^{\star}$ & 0.008 \\
\hline Control & -0.143 & 0.547 \\
\hline
\end{tabular}

${ }^{*}$ Correlation is significant at $p<0.05$.

The bivariate Pearson's correlation coefficient indicates that there was no relationship between the DT and all other variables in the control group. However, in the labourer group, DT correlated positively with all other parameters measured except for the BMI. The possible explanation for these off-control relationships could lie in the fact that the level of respiratory function as a result of DT may have created a structural and functional uniformity, evidenced in the display of positive correlations.

Numerous search engines did not reveal any such study attributed to sub-Saharan Africa. As a result, this is the first such study carried out in sub-Saharan Africa. We hope that the findings here in will serve as a verifiable nomogram and a suitable guidepost in the assessment of the diaphragm, functionally and biomechanically. It has also revealed that for an African population, occupation-related unregulated strength and anaerobic training could increase DT, while hoping that the associated lower weight seen in the quasiexperimental group (labourers) may not be a negative indicator. It will further create possible extensions in the determination of the relationship between respiratory function and DT.

\section{Conclusions}

The thickness of the diaphragm in a sub-Saharan African population is higher among peasant labour- ers than an age-matched, relatively inactive group. This may be associated with their occupation, which involves extreme degrees of physical activity that induce diaphragmatic hypertrophy. Nevertheless, this increased thickness correlated positively with their weight, which may be indicative of the setting in of an atypical situation due to unregulated strength and anaerobic training.

\section{Acknowledgments}

We acknowledge the radiographer C.O. Ogbonna for bringing his experience to bear in the course of carrying out this study.

\section{References}

1. Ahmad I, Kaukab N, Ikram M, Hussain A. Anatomical variations of diaphragmatic crura. Journal of Rawalpindi Medical College 2011; 15: 120-2.

2. Narici MV. Human skeletal muscle architecture studied in vivo by non-invasive imaging techniques: functional significance and applications. J Electromyogr Kinesiol 1999; 9: 97-103.

3. Blazevich AJ, Sharp NC. Understanding muscle architectural adaptation: macro- and micro-level research. Cells Tissues Organs 2005; 181: 1-10.

4. Lieber RL, Friden J. Clinical significance of skeletal muscle architecture. Clin Orthop Relat Res 2001; 383: 140-51.

5. Fukunaga $T$, Ichinose $Y$, Ito $M$, et al. Determination of fascile length and pennation in a contriacting human muscle in vivo. J Appl Physiol 1997; 82: 354-8.

6. Maganaris CN, Baltzopoulos V, Sargeant AJ. In vivo measurements of the triceps surae complex architecture in man: implications for muscle function. J Physiol 1998; 512: 603-14.

7. Rutherford OM, Jones DA. Measurement of fibrepennation using ultrasound in the human quadriceps in vivo. Eur J Appl Physiol Occup Physiol 1992; 65: 433-7.

8. Joris JL, Didier PN, Legrand MJ, et al. Haemodynamic changes during laparoscopic cholecystectomy. Anesth Analg 1993; 76: 1067-71.

9. Koivusalo AM, Kellokumpu I, Scheinin M, et al. A comparison of gasless mechanical and conventional carbon dioxide pneumoperitoneum methods for laparoscopic cholecystectomy. Anesth Analg 1998; 86: 153-8.

10. Koivusalo AM, Lindgren L. Effects of carbon dioxide pneumoperitoneum for laparoscopic cholecystectomy. Acta Anaesth Scand 2000; 44: 834-41.

11. McLaughlin J, Scheeres D, Dean R, Bonnell B. The adverse haemodynamic effects of laparoscopic cholecystectomy. Surg Endosc 1995; 9: 121-4.

12. Mann C, Boccara G, Pouzeratte Y, et al. The relationship among carbon dioxide pneumoperitoneum, vasopressin release, and haemodynamic changes. Anesth Analg 1999; 89: 278-83.

13. Hofer CK, Zalunardo MP, Klaghofer R, et al. Changes in inthrathoracic blood volume associated with pneumoperitoneum and positioning. Acta Anesth Scand 2002; 46: 303-8.

14. Cherniak NS, Haxhiu MA, Mitra J, et al. Response of upper airway, intercostals and diaphragm muscle activity 
to stimulation of oesophageal afferents in dogs. J Physiol 1984; 349: 15-25.

15. Morris JM, Lucas DB, Bresler B. Role of the trunk in the stability of the spine. J Bone Joint Surg Am 1961; 43: 327-51.

16. Lang IM. Digestive tract motor correlates of vomiting and nausea. Can J Physiol Pharmacol 1990; 68: 242-53.

17. Miller AD. Respiratory muscle control during vomiting. Can J Physiol Pharmacol 1990; 68: 237-41.

18. Barnes JH. The physiology and pharmacology of emesis. Mol Aspects Med 1984; 7: 397-508.

19. Dantas RO, Lobo CJN. Contribution of diaphragmatic contraction in the pressure of the lower oesophageal sphincter in patients with Chagas disease. Arq Gastroenterol 1994; 31: 14-7.

20. Sidhu AS, Triadasilopoulos G. Neuro-regulation of lower oesophageal sphincter function as treatment for gastrooesophageal reflux disease. World J Gastroeterol 2008; 14: 985-90.

21. Enright SJ, Unnithan VB, Heward C. Effect of high intensity inspiratory muscle training on lung vols, diaphragm thickness and exercise capacity in subjects who are healthy. Phys Ther 2006; 86: 345-54.

22. McGrath M. True core stability. A summary of why the diaphragm is so important. Extracted from http://www. markmcgrath.com 2012. Assessed on the 20th February, 2014.

23. Wait JL, Nahormek PA, Yost WT, Rochester DF. Diaphragmatic thickness-lung volume relationship in vivo. J Appl Physiol 1989; 67: 1560-8.

24. Ueki J, De Bruin PF, Pride NB. In vivo assessment of diaphragm contraction by ultrasound in normal subjects. Thorax 1995; 50: 1157-61.

25. McCool FD, Benditt JO, Conomos P, et al. Variability of diaphragm structure among healthy individuals. Am J Respir Crit Care Med 2005; 155: 1323-8.

26. Grassi W, Filippucci E, Farina A, Cervini C. Sonographic imaging of tendons. Arthritis Rheum 2000; 45: 969-76.

27. O'Connor P, Grainger AJ, Morgan SR, et al. Ultrasound assessment of tendons in asymptomatic volunteers: a study of reproducibility. Eur J Radiol 2004; 14: 1968-73.

28. Misuri G, Colagrande S, Gorini M, et al. In vivo ultrasound assessment of respiratory function of abdominal muscles in normal subjects. Eur Respir J 1997; 10: 2861-7.

29. Arora NS, Rochester DF. Effect of body weight and muscularity on human diaphragm muscle mass, thickness and area. J Appl Physiol Respir Environ Exerc Physiol 1982; 52: 64-70.

30. Downey AE, Chenoweth LM, Townsend DK. Effects of inspiratory muscle training on exercise responses in normoxia and hypoxia. Respir Physiol Neurobiol 2007; 156: $137-46$.

31. Grosu HB, Lee YI, Lee J, et al. Diaphragm muscle thinning in patients who are mechanically ventilated. Chest 2012 142: $1455-60$.

32. Egwu OA, Njoku CO, Ewunonu EO, et al. Assessment of master muscle thickness in adult Nigeria population: an ultrasound based study. Int J Biomedical Res 2012; 3 : 143-6.

33. Taniguchi N, Miyakoda J, Itoh K, et al. Ultrasonographic images of the diaphragm and respiratory changes on their thickness. Jpn J Med Ultrasonics 1991; 18: 93-8.
34. DuBois D, DuBois EF. A formula to estimate the approximate body surface area if height and weight be known. Arch Intern Med 1916; 17: 863-71.

35. Dureuil B, Matuszak Y. Alteration in nutritional status and diaphragm muscle function. Reprod Nutr Dev 1998; 38: $175-80$

36. Kelsen S, Ference M, Kapoor S. Effects of prolonged undernutrition on structure and function of the diaphragm. J Appl Physiol 2005; 58: 1354-9.

\section{Address for correspondence:}

Ogugua Augustine Egwu $\mathrm{PhD}$

Federal University

Ndufu-Alike Ikwo

PM.B 1010

234 Abakaliki, Nigeria

Phone: +2348034518414

E-mail: egwuoc@gmail.com 